\title{
Exploring Forensic Astrology in Manjiri Prabhu's the Cosmic Clues
}

\author{
Maria Baptist $\mathrm{S}$ and Bhuvaneswari $\mathrm{R}$ \\ School of Social Sciences and Languages, Vellore Institute of \\ Technology, Vandalur, Chennai, Tamilnadu, India \\ Corresponding author email: mariabaptist.s2020@vitstudent.ac.in
}

\begin{abstract}
This paper aims to project a new dimension of the detection of crimes. Most of the time, investigation comprises facts, logic, intuition, etc. In addition to this, investigation advances with the use of forensic science. It progresses the investigation, helps to identify the criminals and solves crimes. There are different types of forensic investigations like cyber Forensics, Forensic Archaeology, Forensic Dentistry, Forensic Entomology and Forensic Astrology. In the novel The Cosmic Clues, the protagonist solves the crimes using Astrology by reading the stars and analysing the horoscopes. Forensic Astrology also helps detectives and police officials to crack criminals. Forensic Astrology uses event charts, last seen charts, horary charts to figure out who is involved, what happened, how and why. While most of us use horoscopes to predict career, marriage, health and many more, the protagonist uses horoscopes to track down the criminals. The paper focuses on The Cosmic Clues by Manjiri Prabhu, a non-stereotypical crime fiction that uses a rare and unusual combination of astrology and investigation in solving crimes. A novel approach to aid the investigation using intellect and cosmic powers is discussed.
\end{abstract}

KEY WORDS: CRIME FICTION, HOROSCOPES, FORENSIC ASTROLOGY, DETECTIVE, INVESTIGATION.

\section{INTRODUCTION}

"As criminologists, astrologers informed clients of everything from a thief's appearance (down to the location of moles) to the direction taken by the culprit and the likelihood of the goods being returned" (Geneva, 1995) Crime and detection always remain inseparable. Crime or detective fiction are sub-divided into a whodunit, hardboiled mystery, locked room mystery, noir fiction, psychothrillers, etc. Crime or Detective fiction with the elements of horror, thrill, mystery and suspense sprang out from Gothic fiction way back in the 19th century. The storyline of crime or detective fiction probes the investigation of murder, rape, honor-killing, robbery and the culprit is revealed or the crime is solved in the end.

Biosc Biotech Res Comm P-ISSN: 0974-6455 E-ISSN: 2321-4007
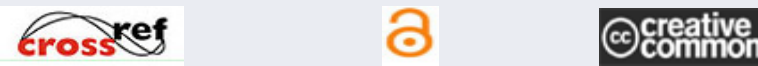

Identifiers and Pagination

Article Information

Year: 2021 Vol: 14 No (8) Special Issue

Pages: 218-221

Received: $28^{\text {th }}$ May 2021

This is an open access article under Creative

Commons License Attribn 4.0 Intl (CC-BY).

DOI: $h t t p: / / d x . d o i . o r g / 10.21786 / b b r c / 14.8 .51$
It narrates the criminal acts, mode of crime committed, the weapons used in the crime and the motive behind the crime scenes which are figured out in the story of detection. The protagonists are mostly private detectives, ex-servicemen and police officials. They take us on a mysterious journey to the world of crimes and untie the knots to find the criminals. The character that plays the role of the detective is often considered as the major character in the story with the task of solving the complicated case. "In the folklore of the "good old days", a detective was considered "as good as his information"-a direct reference to the fact that detectives were expected to cultivate a number of information sources" (Greenwood et al., 1975, p. 29). Nowadays, science and technology aids criminal intelligence and helps in comprehensive criminal investigation to solve crimes. There are different types of forensic investigations like cyber Forensics, Forensic Archaeology, Forensic Dentistry, Forensic Entomology and Forensic Astrology.

Astrology: Astrology is both a science and an art. It deals with the planets, stars, asteroids, etc. The origin of Astrology trace down to Mesopotamia Civilization and with the conquest of Alexander the Great, it evolved 
to all parts of the world. Major works on astrology are Manilius' Astronomicon, Ptolemy's Tetrabiblos, Julius Firmicus Maternus' Mathesis, Albumasar's Introduction to Astrology, Morin de Villefranche's Astrologia Gallica and works of William Lilly and the discoveries of Uranus, Neptune, Pluto, etc. help in acquiring knowledge in Astrology. In 1908, a school of astrology was established in Los Angeles and in 1920 astrology was legalized in New York. In the 1940s, accepted worldwide and continues to grow until today with the support of various scientific inventions. There are different types of Astrology. They are Natal Astrology, Horary Astrology, Event Astrology, Mundane Astrology, Medical Astrology, and Relationship Astrology.

Forensic Astrology: Forensic Astrology is a method to investigate the crimes like finding the missing person and cold cases like murder, serial killings, attacks, etc. using astrology. Forensic Astrologers help the police officials or FBI or private detectives to solve the crimes. In Astrodetective fiction, protagonists employ astrology to solve the crimes and to shortlist the suspects. Similar to Forensic methods like post mortem, identifying fingerprints, etc., Forensic Astrology analyses the information (like the available crime list to track down the real culprit) with the help of astrology and various scientific methods. Forensic Astrology is used at a peripheral level in the works by using horoscopes. Astrologers search the skies for the happenings on the Earth and interpret the clues to make sense. Techniques used in Forensic Astrology are the charts that trace the events that happen and answers the questions related to crime to the astrologers in the form of clues. Various charts like event charts, last seen charts, horary charts, etc. are employed in real-time incidents to solve the crimes.

Literature Review: Astro-detective fiction, a new mystery sub-genre, is the fastest-growing genre in the literary world. The protagonist analyses the clues convert them into evidence and solve the case using Astrology. Most crime fiction delves on the application of various scientific methods (Forensics or Forensics Sciences) to map a missing person and solve crimes, and it is imperative for the readers to know the technical jargon to follow the works. But readers can follow the works without the awareness of Astrology in Astro-detective fiction. The term 'Forensic Astrology' is coined for the usage of Astrology and the application of various scientific methods to solve crimes. Forensic Astrology by Dave Campbell, Forensics by the Stars: Astrology investigates and Exploring Forensic Astrology: The Secrets Behind Famous Family Murders by B. D. Salerno details the usage of charts and demonstrates real-time incidents. The writers of Astro-detective fiction are mostly astrologers like Stevens Forrest's Stalking Anubis (2002), Alan Annand's Scorpio Rising (2011), Harm's Way (2011) and Joyce Mason's The Crystal Ball (2013). Stevens Forrest has written enormous non-fictional books related to Astrology, the well-known and groundbreaking book, The Inner Sky (2012) is about the basics of astrology.
The Cosmic Clues (2004) and Stellar Signs (2015) by Manjiri Prabhu is the first Astro-detective series in India. Sonia Samarth is the protagonist of the novels. The novels deal with astrology and a series of crimes and investigations. The novels help the readers to change their perspective towards astrology and help in the upliftment of society. In India, most of us use astrology to predict the future or to find a match for marriage, career, health and many more. But in the novel, astrology aids in solving crimes that take astrology one step ahead for ordinary things. The paper attempts to interpret a new field of Astro-detective fiction in the light of Forensic Astrology.

Analysis of The Novel: In the novel The Cosmic Clues, the protagonist, Sonia Samarth holds a degree in criminology and runs a detective agency called Stellar Investigation. Her assistant Jatin is an amateur and new to the field of investigation. Inspector Divekar and Sonia help each other to solve crimes. Mohnish Rai, Vivek, Rita, Sub-Inspectors support her in solving crime cases. Sonia solves crime cases using techniques from astrology when unearthing clues become tricky or difficult. Most people come to Sonia to seek advice and predictions, as they mistake her for the astrologer, though she hates horoscope-reading, she reads in unavoidable situations. She does not wholly rely on astrology for the investigation process. She practices forensic astrology, not natal astrology, and analyses the involvement of the person in the crimes. Sonia finds out Varun Thakur aka The Owl, an International criminal crosses her by analysing her horoscope and the novel progresses, whether she finds him or not. Sonia represents the private detectives and investigators who face challenges, obstacles and efforts to crack the cases.

The story revolves around a series of investigations solved by the protagonist, Sonia. Her first case is by Ajay Patkar, to investigate the case of murder of his friend, Satish. Police suspect Naresh and arrest him. Sonia asks for the horoscopes and gains a clue, "It was Mrs.Patkar's horoscope that revealed the criminal traits!" (Prabhu, 2013, p. 52). She suspects Mrs.Patkar and examines in detail: Jupiter in her fifth house is in conjunction with Rahu. Saturn with Ketu, does not aspect the fifth house favourably, and to make matters worse, the swami or the Lord of the fifth house-a house which governs children-is with Saturn...such a woman will never conceive and will never have a child of her own. And even if she did, it will not be a son! (Prabhu, 2013, p. 52). Sonia's horoscope analysis reveals that Ajay is the son of Mr.Patkar who lost his first love during childbirth. The sole owner of the business is Ajay and the next heir is Naresh. As Mrs. Patkar incurs debt, she plans to murder Ajay and trap Naresh. The plan misfires and Satish has died. Sonia succeeds in cracking the case and Mrs.Patkar confesses to Inspector Divekar.

After the celebration of her successful first case, Sonia meets Mr.Tupay's family. Revati and Gaurav are soon to be married and seeks Sonia's help as she receives 
threatening calls not to get married to Gaurav. Sonia reads the horoscope of the family, before she begins, instructs them, "Never lie to the Doctor and Astrologer!...a horoscope is an X-ray of a person. It can tell a lot. Astrology is a science but I combine it with intuition" (Prabhu, 2013, p. 62). She gets approval from the clients to use astrology and solve the situation. Sonia reads the horoscope and assures that they will get married. According to Sonia, the stars in Pradnya Joshi, sister of Mrs.Tupay horoscope says, "You were in love once, but didn't work out, did it?...Harshal or Uranus in the fifth house with Rahu indicates that it could have culminated into marriage...he tricked you!"(Prabhu, 2013, p. 67). Pradnya accepts the truth. As Sonia continues, Pradnya's son is Sushil, the electricity goes off and Pradnya is found dead. Sonia opens up that Sushil is in love with Revati and threatened her. In a fit of anger, over her mother more than the love he had for Revati, he shot Pradnya. By reading Sushil's horoscope in detail: "Moon-the controlling planet of the mind-and Mercury-the planet related to brain and memory-both are in excellent and auspicious conjunction with Jupiter. You wouldn't find a clearer, more logical person with total control over mind and body!'(Prabhu, 2013, p. 80). It indicates that Sushil never met with an accident nor has a memory disorder. Inspector Divekar arrests Sushil and Sonia successfully cracks her second case as well by examining the stars and birth charts.

Neha Gulati saw the obituary and reached Pune in search of her husband. Mohnish Rai guides her to meet Sonia. Mr.Tushar Gulati has died in the name of Mr.Kapoor. Sonia investigates Mrs.Kapoor and Mr.Jaidev, a friend of Mr.Kapoor gets their horoscopes for reading. She interprets, "The Moon, Rahu, Mars and Uranus in Mr.Kapoor's first house and Neptune and Mars in Mrs. Kapoor's first house, face-to-face with Uranus in her seventh house" (Prabhu, 2013, p. 102). Generally, planet to planet horoscope matching is considered in marriages but the horoscope reads a strange combination and the planets were opposite to each other. Then she moves on to Mr.Jaidev's horoscope," Nothing extraordinary about the career, a clean chit on the character front, and the normal ups and downs in life" (Prabhu, 2013, p. 102). Sonia finds out that Tushar and Mr.Jaidev's horoscopes are similar. "This was Mr.Jaidev's horoscope all over again, number by number, star by star!” (Prabhu, 2013, p. 107). To escape bank robbery, they allegedly hid the identity of Mr.Tushar as Mr.Kapoor and Mr.Kapoor as Mr.Jaidev. Even twins do not have the same planets and stars combinations. The identical horoscope helps her investigate and solve the case.

Aarti Vaze has an intuition that something wrong could happen in her marriage, so she decides to hire Sonia, a private detective. Pradeep Gupte, her fiancée, and Meera adopted a sister plan to kill Aarti. Aarti handovers the horoscopes of all the family members to Sonia. By interpreting the horoscope, "Pradeep's Venus and Mars were in the same as his adopted sister Meera's...strongly attracted to each other and were having a relationship... Aarti's horoscope revealed no such bond with Pradeep"
(Prabhu, 2013, p. 140). The similarities between Pradeep and Meera and the dissimilarities between Pradeep and Aarti reveal that they cannot marry. "Pradeep ...had a very unique combination in his horoscope. That his first wife would die and then he would remarry" (Prabhu, 2013, p. 134). So, after marriage, Pradeep and Meera plan to kill Aarti to lead a happy life." Venus and Mars in Aarti's horoscope were so placed, they showed that this girl was going to be badly tricked" (Prabhu, 2013, p. 140). Sonia saves Aarti and arrests Pradeep and Meera. Thus the research paper identifies and brings out the use of forensic astrology in the novel, The Cosmic Clues.

\section{CONCLUSION}

The research paper begins with a general introduction to crime or detective fiction. It traces the origin and brief history of Astrology and its types among which is Forensic Astrology. The paper focuses on The Cosmic Clues by Manjiri Prabhu, a non-stereotypical crime fiction that uses a rare and unusual combination of astrology and investigation in solving crimes. A novel approach to aid the investigation using intellect and cosmic powers is discussed. The shreds of evidence are carved out to get a glimpse of the novel and for the use of forensic astrology to support the detection. The analysis may extend to some of the technical usages like charts, planets, and stars combination. A former Los Angeles Police Department lieutenant wrote...it is not "in the stars for judges to allow astrologers into court" and "the Federal Bureau of Investigation shared that it "does not use astrology in solving crime" (Allen, 2020). Though critiques disagree with the usage of astrology in solving crimes in real-time, with a new broader approach and contribution by the writers to the dual genre, Astrodetective fiction is growing in popularity and perpetuate the literature.

\section{REFERENCES}

Allen, R. (2019). Justice Rising Meet the astrologers who search the skies for clues to earthly crimes.. Holisticpinkprint.com. Retrieved 20 March 2021, from https://www.holisticpinkprint.com/post/astrology-andcrime-solving

Allen, R. (2020). Could the Planets Hold Clues to Earthly Crimes? Forensic Astrologers Are on the Case... Slate Magazine. Retrieved 20 March 2021, from https://slate. com/human-interest/2020/09/forensic-astrology-crimesolving.html

Bhardwaj, M. (2015). A New-Age Astro Detective. The New Indian Express. Retrieved 22 March 2021, from https://www.newindianexpress.com/cities/ bengaluru/2015/feb/03/A-New-Age-Astro-Detective712782.html

Campbell, D. (2004). Forensic Astrology. Arizona: American Federation of Astrologers.

Diaz, A. (2014). The Astrologer Did It: A New Kind of Mystery - Astrology News Service. Astrology News Service. Retrieved 21 March 2021, from https://astrologynewsservice.com/ 
book-reviews/the-astrologer-did-it-a-new-kindof-mystery / \# : :text=There's\%20a\%20new\%20 mystery $\% 20$ subgenre, astrology $\% 20$ to $\% 20$ help $\% 20$ solve\%20mysteries

Forrest, S. (2007). Inner Sky.Seven Paws Press.

Geneva, A. (1995). Astrology and the seventeenthcentury mind: William Lilly and the language of the stars. Manchester University Press.

Greenwood, P. W., Chaiken, J. M., Petersilia, J., EtPrusoff, L. (1975). The criminal investigation process Volume III: Observations and analysis. California: Rand Corporation. Retrieved from https://www.ojp.gov/ pdffiles1/Digitization/148118NCJRS.pdf

Gulino, E. (2020). There Are 80+ Types Of Astrology.
Here's Where To Start. Refinery29.com. Retrieved 24 March 2021, from https://www.refinery29.com/en-us/ types-of-astrology

Mason, J. (2014). Astro-Detective Fiction Author Tells All!. Mandilockley.blogspot.com. Retrieved 25 March 2021, from http://mandilockley.blogspot.com/2014/02/ astro-detective-fiction-author-tells-all.html

Prabhu, M. (2013). The Cosmic Clues. Mumbai: Jaico Publishing House.

Saleno, B. D. (2012). Forensics by the Stars: Astrologers Investigates. Bloomington: iUniverse, Inc.

Sharp, D. (2005). Learning Astrology. San Francisco: Weiser Books 